University of Nebraska - Lincoln

DigitalCommons@University of Nebraska - Lincoln

1976

\title{
THE IMPACT OF COMPUTER GENERATED INFORMATION ON THE CHOICE ACTIVITY OF DECISION-MAKERS
}

Fred Luthans

Robert Koester

Follow this and additional works at: https://digitalcommons.unl.edu/managementfacpub

Part of the Business Administration, Management, and Operations Commons, Management Sciences and Quantitative Methods Commons, and the Strategic Management Policy Commons

This Article is brought to you for free and open access by the Management Department at DigitalCommons@University of Nebraska - Lincoln. It has been accepted for inclusion in Management Department Faculty Publications by an authorized administrator of DigitalCommons@University of Nebraska - Lincoln. 


\section{THE IMPACT OF COMPUTER GENERATED INFORMATION ON THE CHOICE ACTIVITY OF DECISION-MAKERS}

\section{FRED LUTHANS}

University of Nebraska

ROBERT KOESTER

Boise State University

Computerized information systems have a tremendous impact on management decision-making in all modern organizations. Electronic data processing (EDP) departments generate, coordinate, and disseminate much of the information that is used in modern management decision-making. How much influence is this computer generated information per se having on the choice activity of the human decision-maker? To date, very little is known about the answer to this question. Yet, if management is to improve the effectiveness of the decision-making process, the implications of computer generated information must be better understood.

Organizationally, there is evidence that the computer has changed traditional line-staff relationships. In reality, EDP departments may be becoming more line (decision-making authority) oriented as opposed to their traditional staff (advice) role. Such a development can be explained by the reactions of decision-makers to computer generated information. A hypothesis worthy of testing would be that if the decision-maker places a great deal of confidence in the computer, then the EDP department functions more in a line capacity. By the same token, if the decision-maker has little 
confidence in the computer, then the EDP department becomes more of a staff function. In other words, it may be that the way in which the EDP department influences the decision-making process depends, in part, on the reaction of the human decision-makers to the computer itself.

Today's managers can be placed on a continuum of knowledge and practical familiarity with computerized information systems. At one extreme are those managers who are extremely knowledgeable about all aspects of the computer's capabilities, limitations, and functions, and have a great amount of practical experience. On the other extreme are those managers who have virtually no understanding or experience with the computer and its role in decision-making. For the purpose of this study, the subjects are considered to fall into one of two categories - those that tend to have some knowledge and familiarity with the computer's capabilities and limitations (termed "experienced") and those who tend to have very little, if any, familiarity with the computer's capabilities and limitations (termed "nonexperienced").

It was hypothesized that the computer experienced subjects would be more suspicious or less confident of computer derived information than would the nonexperienced. Computer experienced people have often been frustrated by the computer and know its limitations. On the other hand, nonexperienced people may hold the computer in awe and thus place too much confidence in computer generated information. The study reported in this paper was designed to test this hypothesis.

\section{Description of the Study}

The subjects used in the study were undergraduate business administration students at the University of Nebraska who were classified by the experimenters as either computer experienced or nonexperienced. The experienced group $(N=200)$ consisted of students finishing a sophomore course in principles of management which included studying computerized information systems and participating in a computerized management simulation game. The nonexperienced group of subjects $(\mathrm{N}=70)$ consisted of selected students finishing a freshman course in principles of accounting who had no familiarity with the computer and specifically had never (a) written a computer program, (b) participated in a computerized management simulation game (as had each of the members of the computer experienced group), or (c) received computerized information on a regular basis. This subject selection process insured that there were computer experienced and nonexperienced groups. The setting of the experiment was the subjects' regular classroom during classtime.

All subjects were systematically told they were participating in a study to develop a profile of students who would be most successful in advanced study in business administration. They were told to complete some biographical information to add credibility to this premise and they were given a short but very difficult test to determine their aptitude. Because the subjects 
were either already majoring in business administration or presumably wanted to find out if they should be because they were taking a business course, it was assumed that they would try to do as well as possible on the test. The debriefing after the completion of the experiment substantiated this premise.

A 20-question multiple choice test was administered to each subject. The questions resembled those found on the Aptitude Test for Graduate Study in Business (ATGSB). Questions on mathematics, vocabulary, logic, and general knowledge were included. The questions were at such a difficult level that the subjects were very unlikely to have any confidence in their answers. The five possible choices for each question were deliberately designed so that no question had one best answer; for example, "Differential calculus is to integral calculus as algebra is to (a) factor analysis, (b) exponentiation, (c) linear programming, (d) probability theory, (e) derivative extraction." Fifteen of the questions had five possible answers that were all incorrect, and the remaining five questions had five possible answers that were all correct. An example of the former type of question is, "The following word is misspelled: (a) accessible, (b) hierarchy, (c) feasible, (d) vacuum, (e) phenomenal." The subjects were given ten minutes to complete the test, and it was explained that they were to answer each question; they were not penalized for guessing. Thus, the subjects were required to make a choice on 20 very difficult questions with no clear answers in a very short time period.

After completing this virtually impossible test, the experimenter announced to all subjects that he realized that it was a very difficult and perhaps frustrating test and he would give them a five minute period to review each of their answers. The control subiects from both the computer experienced $(\mathrm{N}=80)$ and nonexperienced $(\mathrm{N}=24)$ groups were asked to review the answers on their own during this period and make any changes that they felt were necessary in a separate column on the answer sheet. These control groups were physically separated from the experimental groups. The remaining experienced and nonexperienced groups were then randomly assigned as follows:

Experimental Group I. Computer experienced subjects who were given a computer print-out list of suggested answers during the review period $(\mathrm{N}=61)$.

Experimental Group II. Computer experienced subjects who were given a standard mimeograph list of suggested answers during the review period $(\mathrm{N}=59)$.

Experimental Group III. Nonexperienced subjects who were given a computer print-out list of suggested answers during the review period $(\mathrm{N}=26)$.

Experimental Group IV. Nonexperienced subjects who were given a standard mimeograph list of suggested answers during the review period $(\mathrm{N}=20)$. 
The experimenter instructed each of these four groups to compare their test answers with the list of suggested answers handed out to them. The experimenter carefully pointed out that the suggested answers were compiled from various sources and might or might not be the correct answers to a given question. This was also mentioned at the top of each list. Since there were no single correct answers to the questions on the test, there were also no correct answers suggested by the answer lists. For example, the answer list corresponding to each question stated that, "THE ANSWER TO QUESTION 1 is E," etc. These suggested answers were randomly assigned on the lists.

The suggested answers for the print-out groups were printed by the computer on regular computer print-out paper. The suggested answers for the mimeograph groups were mimeographed on standard white paper. The two lists of answers were identical in every other respect (content, size, form, capitalization, punctuation, spacing, and quality of paper).

The answer sheet contained two columns. The first column contained answers to the questions during the regular time period. The second column contained any changes that were made during the review period. Thus, the exact number of changes could be accurately recorded.

\section{Results and Conclusions}

The mean number of answer changes during the review session by members of each of the six groups (two control groups and four experimental) is summarized in Table 1 . Analysis of variance found a statistically significant difference between each of the subgroups (control, print-out, and mimeograph) within each of the two major classifications (experienced and nonexperienced). $[F(2,197)=16.1, p<.01$ for the computer experienced group, and $F(2,67)=7.5 ; p<.01$ for the nonexperienced group.]

Other than the analysis of variance within the two major groups, no significant difference $(p<.01)$ was found between the means of the experienced and nonexperienced control groups, a result which gives support to the assumption of homogeneity for both the experienced and non-

TABLE 1

Number of Changes in Answers for Computer Experienced and Nonexperienced Subjects

\begin{tabular}{llcc}
\hline Group & $N$ & $\begin{array}{c}\text { Mean Number } \\
\text { of Changes }\end{array}$ & $\begin{array}{c}\text { Standard } \\
\text { Deviation }\end{array}$ \\
\hline Experienced & & & \\
$\quad$ Control & 80 & 2.66 & 2.57 \\
Print Out & 61 & 4.45 & 3.12 \\
Mimeograph & 59 & 5.82 & 4.08 \\
Nonexperienced & 24 & 2.62 & 1.75 \\
$\quad$ Control & 26 & 6.28 & 3.16 \\
Print Out & 20 & 4.10 & 2.21 \\
Mimeograph & & \\
\hline
\end{tabular}


experienced subjects. Since the control groups of both the experienced and nonexperienced subjects had mean changes that were smaller than the means of either the print-out or mimeograph experimental groups, the lists of suggested answers passed out to these latter subjects are shown to have had a significant influence on their choice activity.

The key finding of the study was that the mimeograph group of computer experienced subjects changed more answers than did the computer experienced print-out group. This suggests that computer experienced subjects were less influenced by information that was computer generated than they were by information presented in a more traditional format (mimeograph). On the other hand, the print-out group of nonexperienced subjects changed more answers than the mimeograph group of subjects with no computer experience. In other words, subjects with no computer experience were more influenced in their choice activity by information that was computer generated than by the identical information presented in a more traditional medium.

The results of this study have implications for the decision-making process in modern organizations. Decision-makers should understand the possible bias that computerized information may introduce into the choice activity. Both computer experienced and nonexperienced managers may be affected. Although the print-out groups of experienced and nonexperienced subjects changed significantly more answers than the control subjects, the most important finding was that the experienced print-out group changed significantly less answers than the experienced mimeograph group and the nonexperienced print-out group changed significantly more answers than the nonexperienced mimeograph group. In other words, the implication is that managers with a great deal of knowledge and familiarity with the computer should recognize that their past experience may affect their present judgment in utilizing computer generated information. By the same token, managers with little or no knowledge or familiarity with the computer should recognize and be cautioned that computer generated information is not necessarily equal to or superior to more traditional forms of information. In summary, this study suggests that computerized information per se may bias the choice activity of decision-makers. 